\title{
PRE-FEASIBILITY OF THE ESTABLISHMENT VITAMIN A (RETINOL PALMITATE) INDUSTRY IN INDONESIA
}

\author{
Rizki Wahyuniardi ${ }^{1, *}$, Tjutju Tarliah Dimyati ${ }^{1}$, Yusep Ikrawan² \\ and Tantan Widiantara ${ }^{2}$ \\ ${ }^{1}$ Departement of Industrial Engineering, Universitas Pasundan, Jl. Dr. Setiabudi No. 193, \\ Bandung 40153, Indonesia \\ ${ }^{2}$ Departement of Food Technology, Universitas Pasundan, Jl. Dr. Setiabudi No. 193, \\ Bandung 40153, Indonesia \\ *E-mail : rizki.wahyuniardi@unpas.ac.id
}

\begin{abstract}
The Government regard to the Ministry of health and Ministry of industry make policy in order to prevent an increase in vitamin A deficiency sufferers in Indonesia. The policy made in the Ministerial Regulation No. 87/2013 about SNI mandatory of Palm cooking oil with vitamin A (fortification). The problem is the whole vitamin A circulating domestically is imported products. With the enactment of this policy, then the needs of vitamin A in the country will be very large. Theoretically, Vitamin A can be generated from the content of certain commodities contained vegetable or animal sources available in the country. Until now, there has been no research that explains the availability of animal or vegetable sources as the industrial raw material of Vitamin A. Research shows that availability of animal and vegetable raw materials in Indonesia to support its industry is not sufficient. Delivered also alternative sources of raw materials that can be used as raw material for the manufacture of Vitamin A as Palm cooking oil. In addition, the results of the analysis of the economic establishment of techno-economic industries Vitamin A in Indonesia using Benefit Cost Ratio, showing that this plan is worthy of particular consideration.
\end{abstract}

Keywords: fortification, palm oil, techno-economic, Vitamin A.

(C) RASĀYAN. All rights reserved

\section{INTRODUCTION}

The number of sufferers vitamin A deficiency in Indonesia reached 10 million. The sufferer is composed of a toddler by as much as $37 \%, 17 \%$ of pregnant women and nursing mothers $13 \%{ }^{1}$. Vitamin A deficiency or xerophthalmia cause disruption of the development organs of vision and increased the risk of pain and death from infections such as measles and diarrhea. Meanwhile, the World Health Organization $^{1}$ in 2008 exposed that the sufferer of measles in Indonesia reached 15369 cases that lead to 1.7 million child deaths under 5 years.

To overcome these problems the Government strives to implement programs that can reduce the problem of nutritional deficiency especially vitamin A through ditjenbina nutrition by providing vitamin A supplements to children across Indonesia. It was not until there, the Ministry of health delivered a letter proposal to Menteri Perindustrian regarding mandatory SNI Palm cooking oil with Vitamin A (GK/Menkes/280/VIII/2012) ${ }^{2,3}$. Vitamin A is specified in the form Retinol Palmitate is added into the cooking oil.

Replied to the proposal, the Ministry of industry has issued Ministerial Regulation No. 87/2013 about enforcement of Indonesia national standard (SNI) of cooking oil Palm (MGS) is mandatory ${ }^{4}$. Regulations promulgated on 24 December 2013 oblige the MGS every manufacturer in the form of packaging is required to add the content of Vitamin A.

Based on the combined data of Vegetable Oil industry of Indonesia (GIMNI) ${ }^{5}$, national MGS needs by 2014 reach 5.22 million tons. The total needs of the MGS consist of 12\% in the form of oil packaging, bulk form 25\% and 63\% in the form of precipitation. Meanwhile, BPS data's in 2014 shows that the national edible oil needs for direct consumption by 2013 reached 694,4 thousand tons, so need Vitamin A 
to meet those needs reach 31.2 tons $^{2,6}$. The value retrieved based on SNI cooking oil 7709:2012 explaining that 1 liter of cooking oil should contain 45 International units (IU) of Vitamin A/gram Retinol Palmitate conversion of $1 \mathrm{IU}=0.3 \mathrm{mcg}$ of Retinol Activity Equivalents (RAE) ${ }^{3}$.

The impact of these policies has made the National Vitamin A needs as supplementary material (fortification) MGS rising. Coupled with the presence of producers of Vitamin A has not been in the country that produces Vitamin A in the form of Retinol Palmitate. Therefore, the entire needs of vitamin A as a fortification of the MGS to be imported. GIMNI $(2014)^{5}$ estimates that to meet the needs of the fortification of vitamin A on the MGS by way of import, then Indonesia will need to issue an import fee Rp525 Billion/year.

To answer these problems, then the research is to study raw materials producers of vitamin A, the technology used and pre-investment feasibility the establishment of Vitamin An industry in Indonesia.

\section{EXPERIMENTAL}

The research is descriptive - quantitative problem - solving frame as shown in Figure-1.

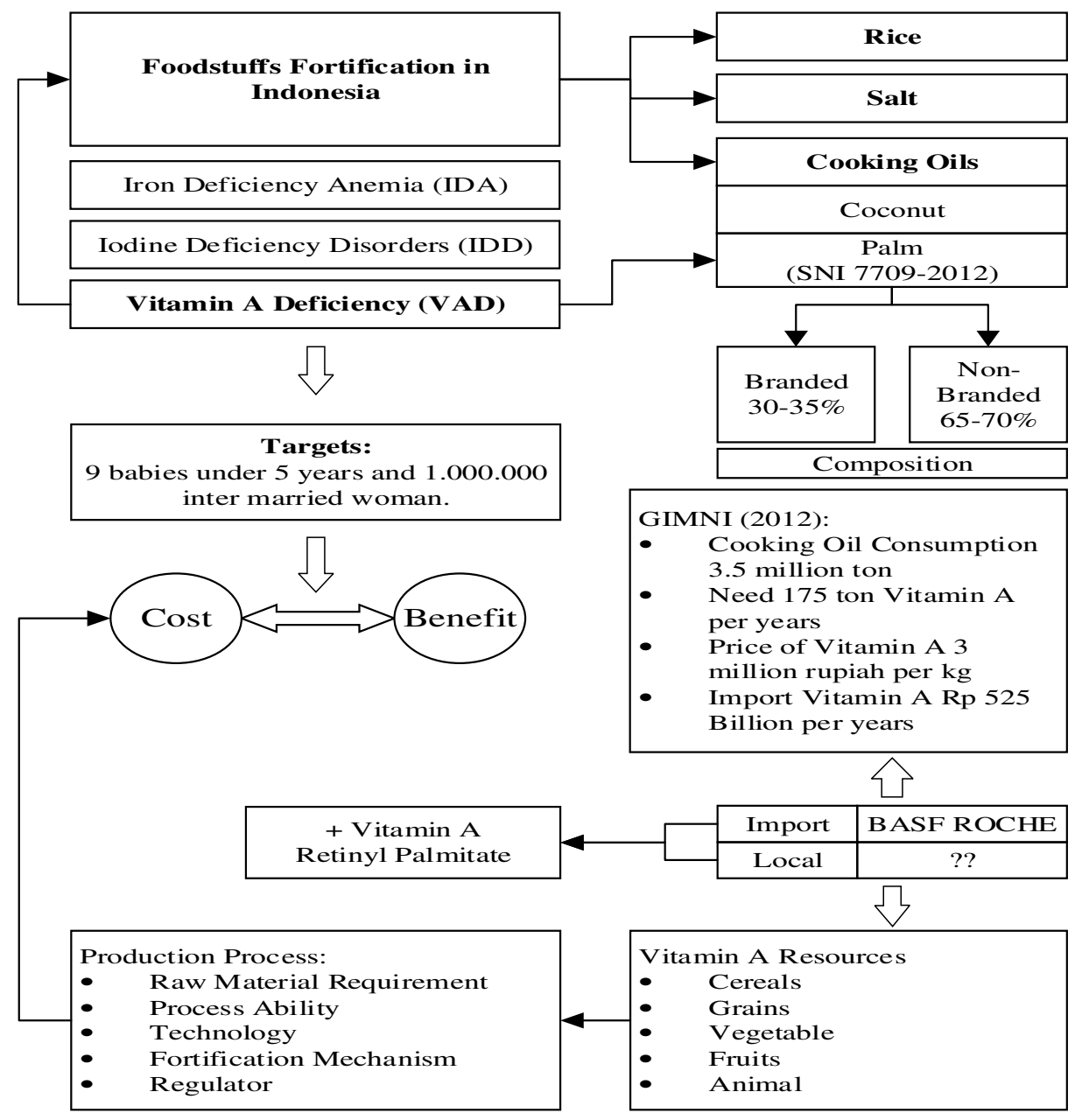

Fig.-1: Problem-Solving Framework

The framework describes a solution that can be done to enhance the Vitamin A consumption society by the fortification of Vitamin A in the form of Retinol Palmitate on foodstuffs. Foodstuffs referred to in this research is the Palm cooking oil.

Meanwhile, the methodology used to complete this study is shown in Figure-2. The first stage is to know the source of the animal and vegetable raw materials as a producer of Vitamin A in Indonesia. Vitamin A 
is Pro-Vitamin A called Retinol Palmitate. Retinol Palmitate is a form of transformation of $\beta$-carotene. With the identification, it can be known to the potential production capacity of Vitamin A which can be generated. If the entire raw material identified do not meet production needs for Vitamin A fortification of MGS, then carried out the identification of advanced against other sources of raw materials, along with the availability of the technological process. According to the Technical Services Branch for the USDA National Organic Program $(2011)^{7}, \beta$-carotene can be generated through chemical extraction, biology, extraction and genetic engineering.

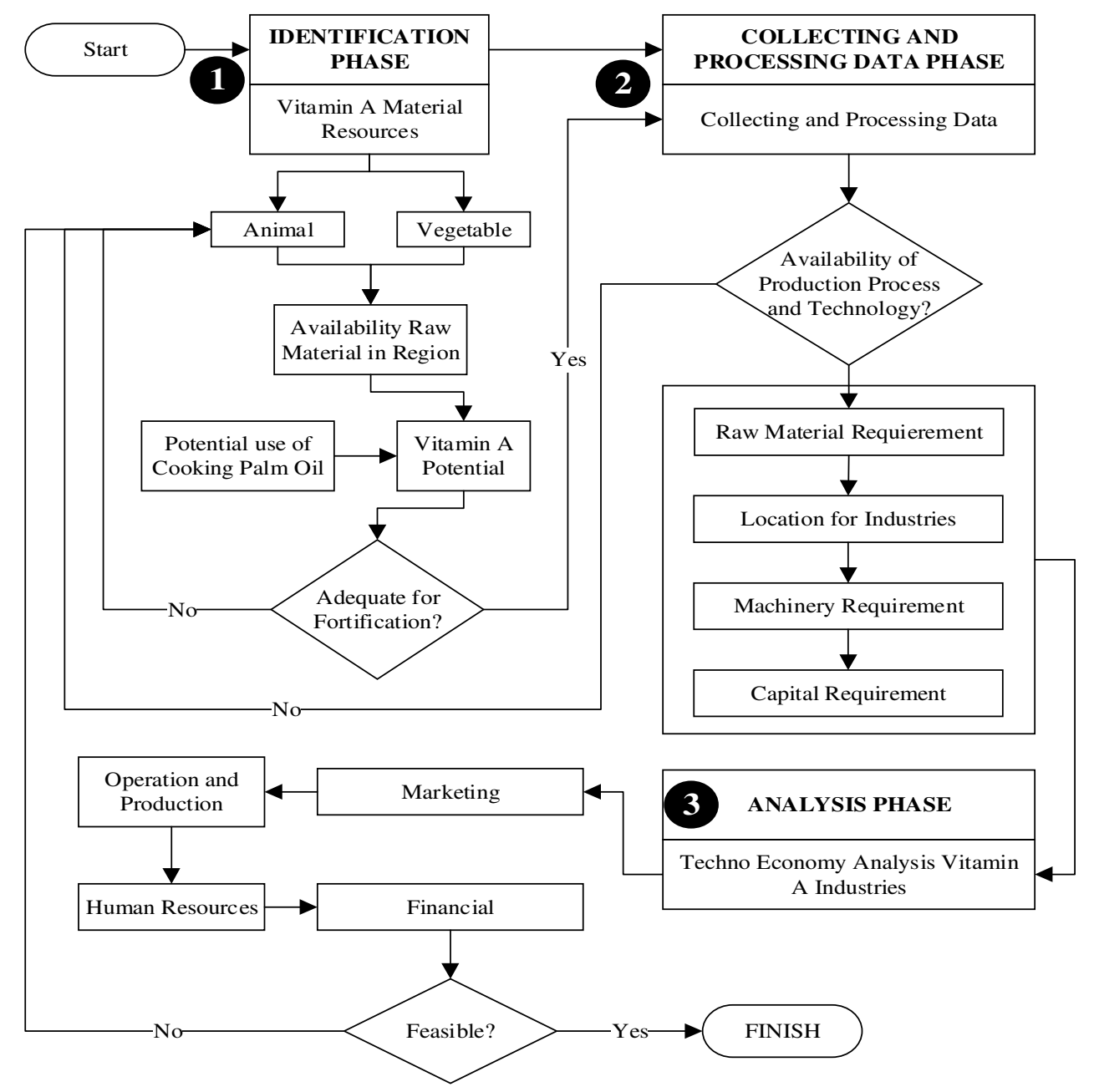

Fig.-2: Research Methodology

The second stage is a stage where the potency of Vitamin A that is produced will be the input for the industry to be built. While the production process and technology will be adapted to the raw material used. Based on the first and second stages, it will be analyzed the feasibility of manufacturing of industrial producers of vitamin A on the third stage. The analysis is made up of market aspects, production and operations, human resources and financial aspects will certainly show that the industry deserves to be built or not.

\section{Sources of Vitamin A Raw materials}

\section{RESULTS AND DISCUSSION}

The survey results showed that the source of raw materials of animals and vegetables raw materials for Vitamin A comes from a source which has a high content of Vitamin A as shown in Table-1 and Table-2. The Raw vegetable is the raw material of commodity that is derived from carrots, spinach, palm oil 
(CPO), tomatoes, Lemongrass, and sweet potatoes. While animal raw materials derived from beef liver, chicken eggs, cow's milk, tuna fish, chicken, and meat.

The amount of vitamin $\mathrm{A}$ in each source either animal or vegetable is calculated based on the content of vitamin $\mathrm{A}(\mathrm{RE}) \mathrm{mcg} / 100$ grams.

Table-1: Vegetable raw materials sources

\begin{tabular}{l|l|l|l}
\hline Comodities & Vit A (RE) mcg/100 gr & Provinces & Production/ years (ton) \\
\hline \multirow{2}{*}{ Carrots } & \multirow{2}{*}{835} & West Java & $1,213,730$ \\
\cline { 3 - 4 } & \multirow{2}{*}{ Spinach } & Central Java & $1,217,444$ \\
\hline \multirow{2}{*}{ Crude Palm Oil } & \multirow{2}{*}{23,700} & West Java & 40,972 \\
\cline { 3 - 4 } & & South of Sumatera & 13,864 \\
\hline \multirow{2}{*}{ Tomatoes } & \multirow{2}{*}{42} & Riau & $6,421,288$ \\
\cline { 3 - 4 } & & South of Sumatera & $4,182,052$ \\
\hline \multirow{2}{*}{ Lemongrass } & \multirow{2}{*}{6} & West Java & 349,583 \\
\cline { 3 - 4 } & & South of Sumatera & 114,168 \\
\hline & & Aceh & 2,195 \\
\cline { 3 - 4 } & West Java & 175 \\
\hline
\end{tabular}

Data processing showed that the vitamin A based on the largest commodity owned by Palm oil (CPO), which is $237 \mathrm{mcg} / \mathrm{gr}$, while the animal is found in the liver of cow is $49,68 \mathrm{mcg} / \mathrm{gr}$.

Table-2: Source of raw materials of animal

\begin{tabular}{l|l|l|l}
\hline Comodities & Vit A (RE) $\mathrm{mcg} / 100 \mathrm{gr}$ & Provinces & Production/ years (ton) \\
\hline \multirow{2}{*}{ Livers of Cow } & \multirow{2}{*}{4,968} & East Java & 15,176 \\
\cline { 3 - 4 } & & Central Java & 6,277 \\
\cline { 3 - 4 } & \multirow{2}{*}{ Eggs } & West Nusa Tenggara & 3,008 \\
\hline \multirow{2}{*}{ Milks } & \multirow{2}{*}{33} & Central Java & 254,800 \\
\cline { 3 - 4 } & & East Java & 253,600 \\
\hline \multirow{2}{*}{ Tunas } & \multirow{2}{*}{556.75} & East Java & 554,312 \\
\cline { 3 - 4 } & & West Java & 281,438 \\
\hline \multirow{2}{*}{ Meat of Chicken } & \multirow{2}{*}{24} & South of Sulawesi & 59,774 \\
\cline { 3 - 4 } & & Jakarta & 29,790 \\
\hline
\end{tabular}

\section{The production process of Vitamin A}

Vitamin A production process is divided into four groups, they are extraction, chemical synthesis, biology and genetic engineering/ biomolecules/pigment (USDA National Organic Program, 2011) ${ }^{7}$ The whole process of this production will produce $\beta$-carotene that is processed back into retinol palmitate.

The production process with chemical synthesis approach is not recommended because it will generate non-natural products and will have an impact if taken in the long term. While for the extraction process is shown in Figure-3, Figure-4 biological processes and biomolecules are shown in Figure-5.

The third process requires two types of main engines, i.e., Fermenters Bioreactor for tissue culture process and Super Critical Fluid Extractor Equipment for the extraction process. While in the process of molecular biology there is a PCR machine serves to the fragmentation of the DNA into the cell.

The manufacture of vitamin A with the extraction process beginning with the extraction of raw materials such as carrots, sweet potatoes, etc. by adding solvents such as hexane, acetone, ethyl acetate, ethanol, and ethyl lactate to produce the desired $\beta$-carotene ${ }^{8}$.

On the process of biological raw materials, which is derived from the fungus blakeslea trispora as microorganisms or $\beta$-carotene obtained from fermentation of blakeslea trispora two types of fungus which 
RASĀYAN J. Chem.

Vol. 10 | No. 1 |99-110 | January - March | 2017

further isolated from the biomass with solvent extraction ${ }^{9}$. Blakeslea Trispora is chosen as the main source of as many produce high $\beta$-carotene ${ }^{10}$.

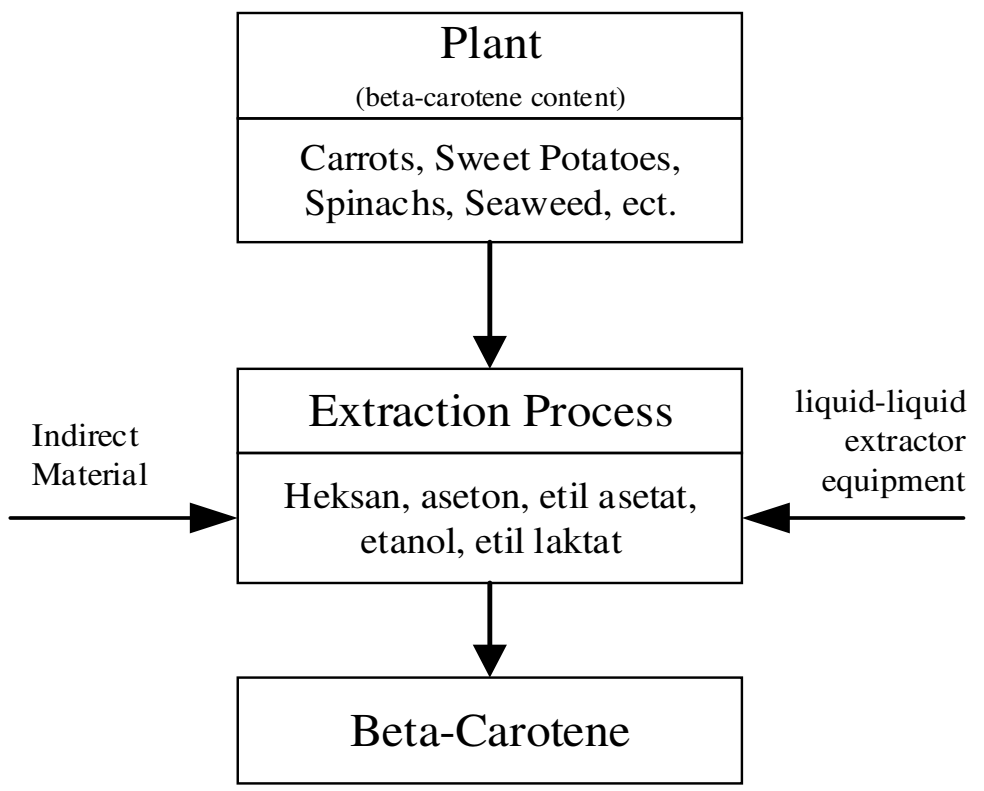

Fig.-3: The manufacture of vitamin A with the extraction process

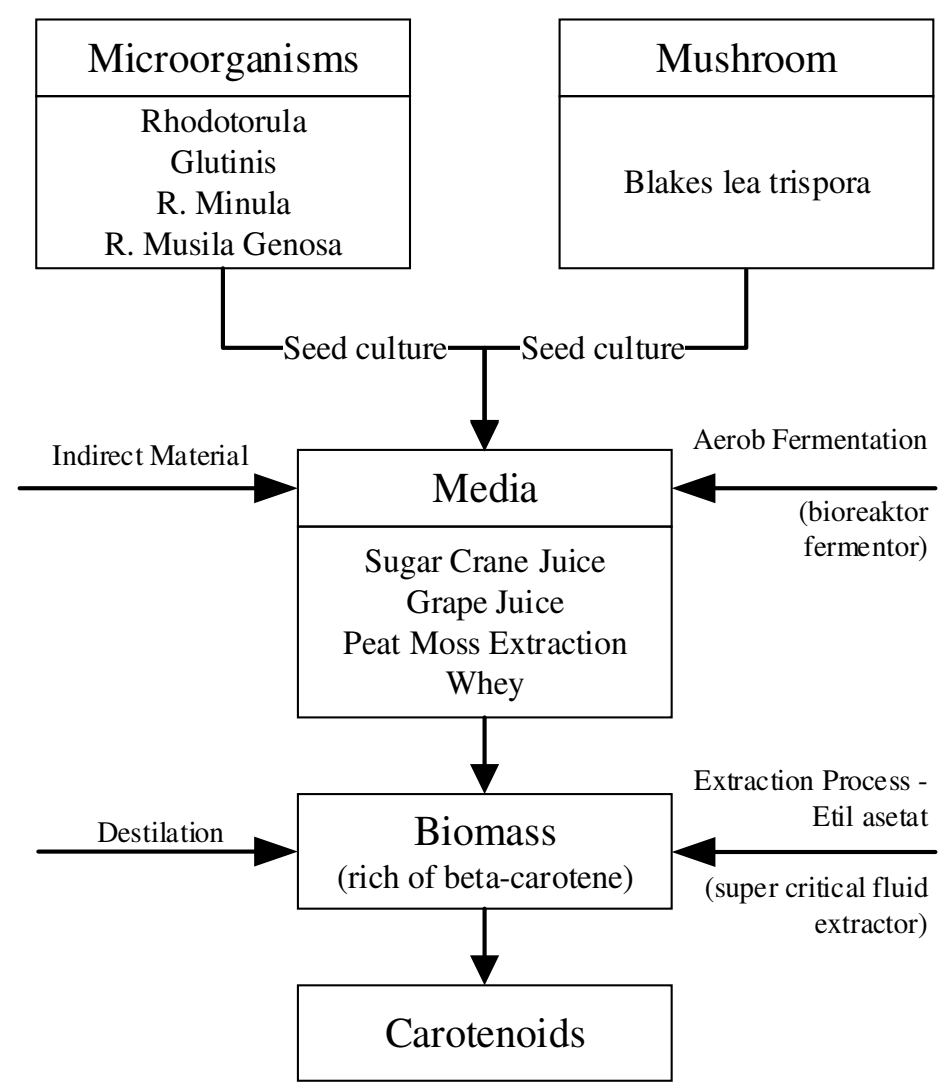

Fig.-4: The manufacture of Vitamin A by biological processes 
RASĀYAN J. Chem.

Vol. 10 | No. 1 |99-110 | January - March | 2017

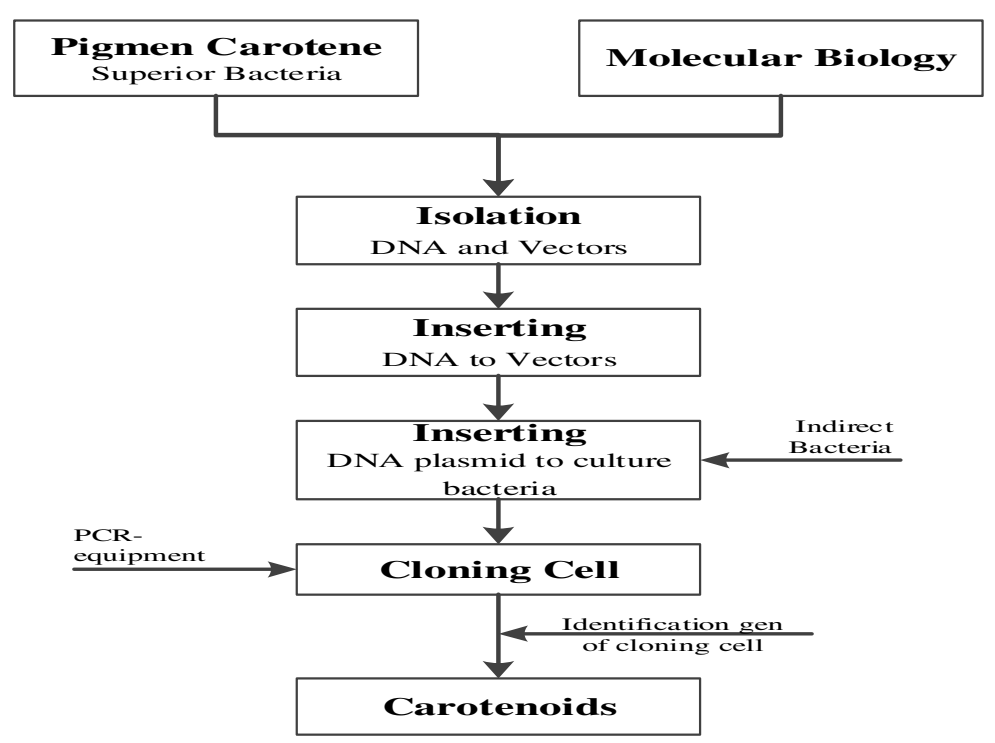

Fig.-5: The manufacture of vitamin A with molecular biology processes/pigments

The manufacture of vitamin A with the molecular biology of this process is the most difficult process compared to the two previous processes. The same raw materials used by biological processes, but the difference is the process of insulation and insertion vector DNA and DNA in the bacterial culture so that it will be acquired bacteria that produce a high $\beta$-carotene ${ }^{11}$.

After the third $\mathrm{b} \beta$-carotene obtained from the process, the next step is the process of synthesis or process enzymatic. Of this process, it will be generated retinol palmitate as shown in Figure-6.

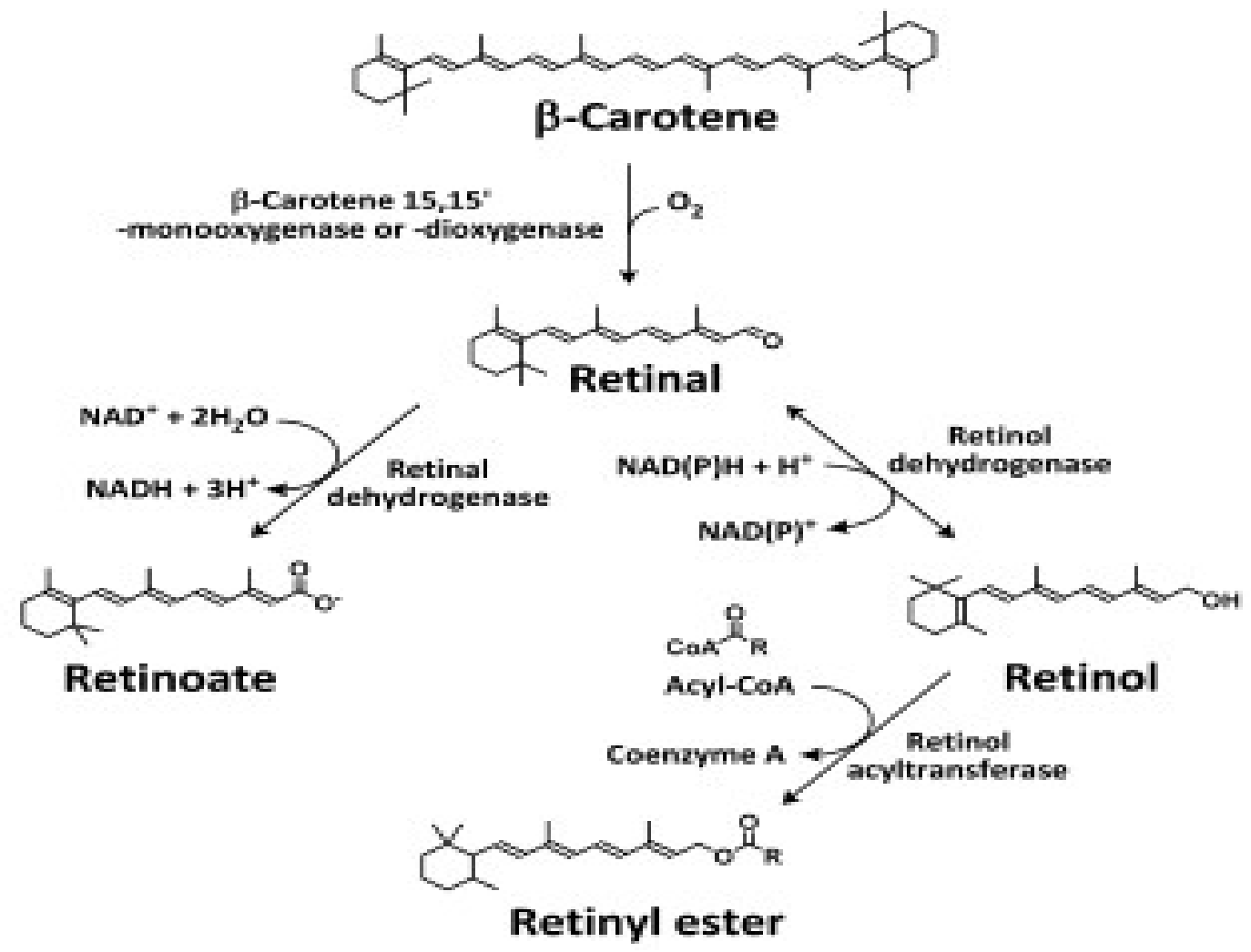

Fig.-6: The change of the structure becomes a retinol $\beta$-carotene with enzymatic process ${ }^{12}$ 
Based on the third production process, it can be done an analysis of the assessment of raw material, materials, auxiliary machinery, products and prices of products in order to find out more economical production processes and can be implemented in Indonesia as seen in Table- 3 and Table- 4 .

Table-3: The condition of the raw materials, materials, and auxiliary machinery

\begin{tabular}{l|l|l|l|l|l|l}
\hline \multirow{2}{*}{ Processes } & \multicolumn{2}{|c|}{$\begin{array}{c}\text { Raw } \\
\text { Material }\end{array}$} & \multicolumn{2}{c|}{$\begin{array}{c}\text { Auxiliary } \\
\text { Material }\end{array}$} & \multicolumn{2}{c}{$\begin{array}{c}\text { Machines } \\
\text { and Tools }\end{array}$} \\
\cline { 2 - 7 } & Int. & Dom. & Int. & Dom. & Int. & TTG \\
\hline $\begin{array}{l}\text { Chemical } \\
\text { Syntheses }\end{array}$ & & $\mathrm{v}$ & $\mathrm{v}$ & & & $\mathrm{v}$ \\
\hline $\begin{array}{l}\text { Biology } \\
\text { Process }\end{array}$ & $\mathrm{v}$ & & & & & $\mathrm{v}$ \\
\hline Extraction & & $\mathrm{v}$ & $\mathrm{v}$ & & & $\mathrm{v}$ \\
\hline $\begin{array}{l}\text { Molecular } \\
\text { Biology }\end{array}$ & $\mathrm{v}$ & & $\mathrm{v}$ & & $\mathrm{v}$ & \\
\hline
\end{tabular}

Source: Research, 2014

Based on Table-3, the raw materials for the extraction process, while all the helper is only found in foreign countries and availability of machinery does not exist in the country. As for quantity, a process that will generate a lot of $\beta$-carotene is a chemical process and the extraction process. However, the extraction process will produce a product price is more expensive compared to chemical synthesis process. Because the chemical process is not recommended by the Government, so the production process that may be done in Indonesia is the biological processes and the extraction process.

Table-4: The quantity and price of the product

\begin{tabular}{l|l|l}
\hline \multirow{2}{*}{\multicolumn{1}{c|}{ Processes }} & \multicolumn{2}{c}{$\beta$-Carotene } \\
\cline { 2 - 3 } & \multicolumn{1}{c}{ Product Quantity } & \multicolumn{1}{c}{ Price } \\
\hline Chemical Syntheses & Many & Cheap \\
\hline Biology Process & A few & Expensive \\
\hline Extraction & Many & Expensive \\
\hline Molecular Biology & A few & Expensive \\
\hline Source:
\end{tabular}

Source: Analysis, 2014

\section{Market analysis of Vitamin A Retinol Palmitate}

Growing needs of the national edible oil amounting to 7\%, it is predicted by 2013 needs cooking oil reached 5.6 million tons (Industrial Ministry of Indonesia, 2009 is being processed). This need consist of two types namely branded cooking oil and non-branded cooking oil as shown in Table-5.

Table-5: The national edible oil needs

\begin{tabular}{c|c}
\hline Cooking Oil & 2013 \\
\hline Branded (37\%) & $2,107,285.05$ \\
\hline Non Branded (63\%) & $3,588,079.94$ \\
\hline
\end{tabular}

Source: Industrial Ministry of Indonesia, 2009, treated $^{2}$

Based on those needs then the amount of vitamin A retinol palmitate needed for branded cooking oil (branded) as much as 147,509 tons/year. This value is retrieved from the conversion needs of vitamin A in $1 \mathrm{~kg}$ of MGS is as much $0.07 \mathrm{~kg}$.

\section{Analysis of the selection process of the production of Vitamin A Retinol Palmitate}

Based on the previous explanation, vitamin A production process that may be implemented in Indonesia is the production process by means of extraction and biology. However, the production process chosen is 
RASĀYAN J. Chem.

Vol. 10 | No. 1 |99-110 | January - March | 2017

the biological process because of consideration of the raw materials available in large quantities and the ease of the process.

\section{Analysis of the Techno-Economic of biological process}

The production process in biology it must meet the needs of the national vitamin A of 147,509 tons/year. To meet the needs of the machine/equipment needed are shown Table- 6 .

Table-6. Machine Needs

\begin{tabular}{l|c|c}
\hline \multicolumn{1}{c|}{ Machine } & Qty & Prices (Rp) \\
\hline Fermentor Bioreactor & 13 & $3,000,000,000$ \\
\hline Super Critical Fluid Equipment Extraction (2000 Liter) & 1 & $120,000,000,000$ \\
\hline
\end{tabular}

Source: Analysis, 2014

In addition to the main equipment, also required infrastructure as well as supporting laboratory technology as shown in Table-7.

Table-7: Laboratory facilities and infrastructure

\begin{tabular}{l|r}
\hline Machines & \multicolumn{1}{c}{ Price (Rp) } \\
\hline High Performance Liquid Chromatography & $240,000,000$ \\
\hline Spectrophotometer UV - Visible & $40,320,000$ \\
\hline Glass Ware Equipment & $40,000,000$ \\
\hline Chemicals & $400,000,000$ \\
\hline Maintenance & $72,032,000$ \\
\hline Total & $792,352,000$ \\
\hline Source: Analysis, 2014
\end{tabular}

Meanwhile, the average cost of production of Vitamin A is influenced by the price of the culture of blakeslea trispora for pure breeds and molasses which became the main ingredient in the manufacture of vitamin A with biological processes as shown in Table-8.

Table-8: The production cost of making Vitamin A with biological processes (MGS Branded)

\begin{tabular}{l|r|c|r}
\hline Direct Raw Material & Qty Fermentor & $\begin{array}{l}\text { Price (Rp) } \\
(1000)\end{array}$ & Total Price (Rp) (1000) \\
\hline Mikroba & 13 & $60,000,000$ & $780,000,000.00$ \\
\hline Molase & 13 & 988,120 & $12,845,560.00$ \\
\hline Indirect Raw Material & $\begin{array}{l}\text { Qty } \\
(1000)\end{array}$ & $\begin{array}{l}\text { Price (Rp) } \\
(1000)\end{array}$ & Total Price (Rp) (1000) \\
\hline \begin{tabular}{l|c} 
Packaging \\
$5 \mathrm{~kg}$
\end{tabular} & 14,500 & $427,778,864.43$ \\
\hline Total (Rp) & $1,220,624,424.43$ \\
\hline Direct Labor & $1,980,000.00$ \\
\hline Indirect Factory Cost & $72,032.00$ \\
\hline Maintenance and Utility & & $1,222,676,456.43$ \\
\hline Total Production Cost (Rp) \\
Source: http://elisa.ugm.ac.id/13
\end{tabular}

Blakeslea trispora mold needs molasses to produce biomass. Biomass is needed as much as 100,000 liters every single fermenter, with the price of molasses per 1 kilogram i.e. Rp7,000. Based on the literature, heavy type of molasses that is $1.4116 \mathrm{~g} / \mathrm{l}$, so the mass of molasses needed for 1 of the fruit is as large fermenters $141,160 \mathrm{~kg}$ or if in rupiahs is Rp988,120.00. Same is the case with the needs of blakeslea trispora, in an effort to meet the needs of production 1,300 tons/72 hours then needed 13 fruit fermenters, 
RASĀYAN J. Chem.

Vol. 10 | No. 1 |99-110 | January - March | 2017

assumed the volume of fermenters is met by the molasses, so obtained the price of molasses of Rp12,845,560,000.

After the $\beta$-carotene is produced from the second stage of the process, namely the process of recovery, carotene packaged in a bottle made from aluminum cans with a capacity of 5 pounds. The aluminum cans protect carotene or vitamin A Retinol Palmitate because translucent so it can protect from heat, caused by light at the storage. Unit price bottle capacity i.e. Rp105,000 for 5 kilograms, and to package the whole of $\beta$-carotene or vitamin A Retinol Palmitate produced, it takes as much packaging of 29,501,991 bottles with a capacity of 5 pounds. Calculation of cost of goods production with that explanation can be seen in Table-9.

Table-9: The price of the staple production manufacture of vitamin A with biological processes (MGS Branded)

\begin{tabular}{l|r}
\hline \multicolumn{1}{c|}{ Indicators } & \multicolumn{1}{c}{ Price $(\mathrm{Rp})$} \\
\hline Invest & $1,412,162,560$ \\
\hline Direct Material & $7,928,455,600$ \\
\hline Indirect Material & $3,097,709,018,424$ \\
\hline Salary & $198,000,000$ \\
\hline Maintenance & $60,000,000$ \\
\hline Overhead & $792,845,560$ \\
\hline Total & $4,119,035,390,424$ \\
\hline Tax $(10 \%)$ & $411,903,539,042.4$ \\
\hline Total & $4,530,938,929,466.4$ \\
\hline Amount of Production & 1,560 \\
\hline COGM/ton & $29,044,480$ \\
\hline COGM/ton & 29,044 \\
\hline COGS (5 liters) & $290,444.8$ \\
\hline
\end{tabular}

Source: Analysis, 2014

\section{The Analysis of The Benefit of Making The Vitamin A Retinol Palmitate}

The fortification of vitamin A Retinol Palmitate into cooking oil is one of the effective ways to provide vitamin A to children and toddlers including communities, considering about $70 \%$ of society Indonesia every day consume vegetable oil. This is done in order for tackling vitamin A deficiency in toddlers, pregnant women, and nursing mothers.

According to the $\mathrm{WHO}^{1}$, an average of $37 \%$ of the total toddler in Indonesia suffered vitamin A deficiency that caused the toddler often affected xerophthalmia, also according to the data of the World Bank $^{14,15}$ that $20 \%$ of the number of pregnant women and $13 \%$ of the total number of nursing mothers in Indonesia suffered vitamin A deficiency which causes a risk to pregnant women a miscarriage or infant who is born has a disability, while in nursing mothers who lack vitamin A so her baby will also experience a Vitamin A deficiency. Data on the percentage of the population who experienced Vitamin A Deficiency (VAD) in Indonesia, can be seen in Table-10.

Table-10: The population who experienced a shortage of Vitamin A in Indonesia

\begin{tabular}{c|c|c}
\hline Parameter & Percentage & Total \\
\hline Babies under 5 years & $37 \%$ & $9,221,051$ \\
\hline Pregnant & $17 \%$ & 848,895 \\
\hline Nursing Mothers & $13 \%$ & 619,648 \\
\hline \multicolumn{2}{r}{ Total VAD } & $10,689,595$ \\
\hline
\end{tabular}

Source: WHO, 2011

The disease caused due to VAD, in general, include xerophthalmia ornyctalopia which caused permanent blindness. Assuming the cost of healing is taken from the maximum cost of treatment of diseases of the eye, for example healing through LASIK surgery worth $\mathrm{Rp} 28,000,000$ per operation. The benefits that can 
be generated when toddlers, pregnant women and nursing mothers consuming cooking oil fortified Vitamin A is the savings towards the cost of treatment which amounted to Rp299,308,654,961,655.

Based on the criterion of benefit, the reduction of benefits (disbenefit), and cost arising from the manufacture of Vitamin A Retinol Palmitate for the fortification of edible oil palm, then it can be calculated the feasibility of manufacturing of Vitamin A Retinol Palmitate. Criteria benefits derived from cost savings arising in the community affected by the lack of Vitamin A Retinol Palmitate can be anticipated.

Disbenefit criteria obtained from the impact caused from the fortification of Vitamin A Retinol Palmitate against edible oil that is consumed when suffering from cancer continued for 10-20 years. Meanwhile, the criteria of the cost are obtained from the production cost of making Vitamin A Retinol Palmitate as shown in Table-11.

Table-11: Feasibility analysis of BCR (side of the businessmen)

\begin{tabular}{l|l|r}
\hline No. & Parameters & \multicolumn{1}{|l}{ Price $(\mathrm{Rp})$} \\
\hline 1 & Benefit (B) & $299,308,654,961,655.00$ \\
\hline 2 & Side Effect (E) & $293,673,120,806,120.00$ \\
\hline 3 & B-E & $5,635,534,155,535.12$ \\
\hline 4 & Cost (C) & $3,977,819,134,423.98$ \\
\hline 5 & (B-E)/C & 1.42 \\
\hline
\end{tabular}

Source: analysis, 2014

From the table above, it can be shown that the value of the resulting ratio is 1.08 means making Vitamin A Retinol Palmitate for fortification is deserves to do. But it needs to be examined again because of the side effects resulting from fortification is very large, that are at risk of various diseases for consumers when consumed continuously.

From the side of the businessmen, B/C can be calculated by considering the cost of sales with profits investments is issued. If it is assumed that the selling price of Vitamin A Retinol Palmitate is Rp300,000 assuming that the advantage gained is 5 times the price of the staple production, then the value of $\mathrm{B} / \mathrm{C}$ are shown in Table-12.

Table-12: Feasibility analysis of BCR (side of the businessmen)

\begin{tabular}{c|c|c}
\hline No. & Parameters & Price (Rp) \\
\hline 1 & Benefit (B) & $4,282,251,396,000$ \\
\hline 2 & Side Effect (E) & - \\
\hline 3 & B-E & $4,282,251,396,000$ \\
\hline 4 & Cost (C) & $3,977,819,134,423$ \\
\hline 5 & (B-E)/C & 1.08 \\
\hline
\end{tabular}

Source: Analysis, 2014

\section{CONCLUSION}

- The potential of the raw materials available from animal and vegetable sources amounted to 15078.14 tons/year. This value is the amount of vitamin A contained in the raw material after the extraction process. Based on that data, then the total availability of the commodity source of raw material for very small national vitamin A needs for the manufacture of vitamin A retinol palmitate.

- The process of making vitamin A grouped into the chemical and natural process, both groups divided into four processes, i.e. the process of chemical synthesis, biological processes, the process of extraction, and the pigment molecules and biological processes.

- The chemical process does not demand by the industry because the products are not produced naturally.

- The natural process basically revamps the structure of certain raw materials to produce a structure of retinol palmitate as needed. The preliminary research required and provision of an expensive high technology to be able to produce to industrial scale. 
- Technology/tools needed for industrial-scale extraction process include: (a) Before the extraction: Conveyor Belt, i.e. Floating Washer, Dryer Drum, Disc Mill, Reflux, and Soxhlet, (b) Extraction process: Super Critical Extraction Plant Fluid, as well as packaging with Bottle Packaging Machine.

- The process of production $\beta$-carotene by using Palm oil, required different production processes with the production process in making CPO or biodiesel. Required oil palm processing specifically so that it can maintain the content of $\beta$-carotene in oil palm. Pigment research required in advance so that it takes a relatively long time and high costs for research and development, process scale-up.

- The process of the production of vitamin A with biological processes is not too dependent on the availability of raw materials. This is because the raw materials used are microorganisms (fungi, yeast or bacteria) that can produce with biological processes. The fungus that produces $\beta$-carotene is the fungus blakeslea trispora, as a filament (a variant of tropical plants) and phycomycosis blakesleanus. This process is in two stages, the first stage of which is fermented by yeast for approximately 72 hours. $\beta$-carotene produced is then isolated from the biomass with the extraction solvent (ethyl acetate) so $\beta$-carotene will crystallize from a solvent carrier. After purified by distillation process then it will result in Vitamin A retinol palmitate. The tools needed are Fermenters Bioreactor, Fluid Super Critical Extraction Plant, and Packaging Bottle Packaging Machine.

- Results of feasibility analysis with the benefits cost ratio for MGS-branded retrieved: (a) The analysis of the $\mathrm{B} / \mathrm{C}$ ratio is applied to the process of making vitamin $\mathrm{A}$ in biology, (b) Costs arising from the need of Vitamin A in the edible oil palm branded (37\%) i.e. 2.1 million tons ${ }^{16}$. By comparison 1:0.07 $\mathrm{kg}$ vitamin A, then it needs to meet the vitamin A fortification process was 147,509 tons/year or 12292.5 tons/month, (c) The proposed industrial Capacity comes on Best Available Technology is there, namely in the amount of 1300 tons/3 days, (d) The value of the resulting BCR is 1.42 (Government side) and 1.08 (entrepreneurs side) so it deserves to be continued, (e) The negative effects from the consumption of palm oil fry with the fortification of vitamin A with estimated disbenefit of Rp293,673,120,806,120.

\section{Recommendations}

From the problems of availability of raw materials, production process, and the technologies used, hence the recommendation that can be given are as follows:

1. Raw materials

i. Optimizing raw material resources available taking into account the content of $\beta$-carotene in raw materials such as carrots, sweet potatoes, and spinach which have a high content of $\beta$-carotene.

ii. Expand land extensification of production of the raw materials needed for industry, especially for Vitamin A Retinol Palmitate industries.

iii. Extraction process with the raw materials of animal (eggs, milk, liver, tuna) has not much to do. Therefore, programs/activities that are recommended are doing further studies towards the extraction process with animal raw materials.

iv. The cultivation of fungus Blakeslea Trispora as raw materials containing high $\beta$-carotene.

\section{Production process}

i. Create a team reviewing the process of the production of vitamin $\mathrm{A}$ in biology, which is equipped with laboratory research and the tools needed to support the industrial development of Vitamin A Retinol Palmitate.

ii. Production Equipment already available in the national/international market and can be developed accordance with national needs.

\section{B/C Ratio}

i. The value of the Benefit Cost Ratio derived more than 1 means the manufacture of Vitamin A Retinol Palmitate worth doing. The value of the feasibility of BCR this Government considers value disbenefit of Palm cooking oil fortified Vitamin A Retinol Palmitate by society at 
large. From the side of the employers, the suggested selling price is very low compared to imported products. If the enlarged approach product pricing imports, $\mathrm{B} / \mathrm{C}$ it will become larger and become a very viable.

ii. Redenomination-done for implementation of fortification of Vitamin $\mathrm{A}$ in the edible oil palm, because the great benefit is directly proportional to the side effects (loss) arising in the future for the customers (Indonesia Society).

\section{REFERENCES}

1. WHO, Vitamin A supplementation in infants and children 6-59 months of age, Geneva 27, (2011).

2. Badan Standarisasi Nasional, 2002, SNI 01-3741-2002: Minyak Goreng.

3. Badan Standarisasi Nasional, 2012, SNI 7709:2012: SNI Minyak Goreng Sawit.

4. Peraturan Menteri Perindustrian (Industrial Ministry of Indonesia Law) No. 87/2013 tentang Pemberlakuan Standar SNI Minyak Goreng Sawit secara Wajib.

5. http://www.gimni.org/.

6. Badan Pusat Statistik (BPS), Statistic of Indonesia, 2014, Indonesian MGS consumption.

7. https://www.ams.usda.gov.

8. B.K. Ishida and M.H. Chapman, Journal of Agricultural and Food Chemistry, 57, 1051 (2009).

9. H.D. Silva, M.A. Cerqueira, B.S.W. Souza, C. Ribeiro, M.C. Avide, M.A.C. Quintas, J.S.R. Coimbra, M.G. Carneiro-da-Cunha, and A.A. Vicente, Journal of Food Engineering, 102, 130 (2011).

10. C. Echavarri-Erasun and E.A. Johnson, 2002, Fungal carotenoids, in: G.G. Khachatourians and D.K. Arora (Eds.), Agriculture and Food Production, Elsevier Science, Amsterdam, pp.45-85.

11. L. Dufossé, P. Galaup, A. Yaron, S.M., Arad, P. Blanc, K.N.C. Murthy, G.A. Ravishankar, Trends in Food Science \& Technology, 16, 389(2005).

12. http://www.nutridesk.com.au/vitamin-a-carotenoids-and-beta-carotene.phtml.

13. http://elisa.ugm.ac.id/.

14. World Bank Institute (WBI), Faire Tache d'Huile: Cooking Oil Fortification in West Africa, (2009).

15. World Bank, Nutrition at a glance in Indonesia, (2010).

16. Badan Pusat Statistik (BPS) in Kementerian perindustrian (Industrial Ministry of Indonesia), 2009, Consumption MGS in Indonesia.

[RJC-1547/2016] 